\title{
PENGEMBANGAN SISTEM PENILAIAN KEMATANGAN TANDAN BUAH SEGAR KELAPA SAWIT MENGGUNAKAN CITRA 680 DAN 750 NM
}

\author{
Agung W. Setiawan*1, Alfie R. Ananda ${ }^{2}$ \\ ${ }^{1}$ Teknik Biomedika, Sekolah Teknik Elektro dan Informatika ITB \\ ${ }^{2}$ Program Magister Teknik Elektro, Sekolah Teknik Elektro dan Informatika ITB \\ Email: ${ }^{1}$ awsetiawan@stei.itb.ac.id, ${ }^{2}$ ananda.alfie@students.itb.ac.id \\ *Penulis Korespondensi
}

(Naskah masuk: 24 Oktober 2019, diterima untuk diterbitkan: 10 Februari 2020)

\begin{abstract}
Abstrak
Salah satu permasalahan utama dalam industri kelapa sawit adalah proses sortasi Tandan Buah Segar (TBS) di pabrik kelapa sawit. Parameter yang digunakan dalam sortasi TBS adalah jumlah brondolan kelapa sawit. Pada saat ini, sortasi dilakukan oleh grader yang bersifat subyektif dan sering kali tidak konsisten. Hal ini terjadi karena keterbatasan penglihatan dan kemampuan manusia untuk mengolah informasi jumlah brondolan setiap TBS dalam waktu yang terbatas. Oleh karena itu, pada penelitian ini dikembangkan sistem penilaian kematangan TBS kelapa sawit berbasis spektroskopi dan nilai kontras citras. Sumber cahaya yang digunakan pada penelitian ini adalah lampu berjenis Light-emitting Diode (LED) dengan panjang gelombang 680 dan $750 \mathrm{~nm}$. Akuisisi citra TBS dilakukan dengan menggunakan kamera DSLR yang telah dimodifikasi. sehingga diperoleh dua citra TBS pada panjang gelombang 680 dan $750 \mathrm{~nm}$. Kemudian, dilakukan perhitungan nilai kontras kedua citra tersebut. Dalam penelitian ini, terdapat 24 TBS yang digunakan sebagai data latih, dengan komposisi 10 TBS matang dan 14 TBS mentah. Data uji yang digunakan berjumlah 77 TBS yang terdiri dari 38 matang dan 39 mentah. Pada penelitian ini, Support Vector Machine (SVM) digunakan sebagai metode klasifikasi. Akurasi data latih yang diperoleh adalah 66,67\%. Sedangkan akurasi data uji dari sistem yang dikembangkan dalam penelitian ini adalah 57,14\%. Hasil yang diperoleh ini masih perlu diperbaiki untuk meningkatkan akurasi sistem dengan cara menambah jumlah data, baik data latih maupun uji, serta menggunakan pembelajaran mesin.
\end{abstract}

Kata kunci: citra $680 \mathrm{~nm}$, citra $750 \mathrm{~nm}$, estimasi kematangan TBS, kontras citra, spektroskopi

\section{DEVELOPMENT OF COMPUTER-AIDED GRADING SYSTEM FOR PALM OIL FRESH FRUIT BUNCH USING 680 AND 750 NM IMAGE}

\begin{abstract}
One of the main problems in the palm oil industry is the grading of Fresh Fruit Bunches (FFB) in the palm oil mills. The parameter used for the process is the number of fruitlets detached from the bunch. Nowadays, the FFB grading is conducted by graders which is subjective and often inconsistent due to the limitation of human vision and ability to process information on the number of fruitlets detached per FFB in a very limited time. Therefore, this study developed a grading system to assess and estimate the FFB maturity based on spectroscopy and image contrast value. From the literature review, visible light and NIR spectrum in 680 and $780 \mathrm{~nm}$ can be used as light sources to detect the maturity level of FFB. DSLR camera is used to acquire the FFB image. Using this scheme, two FFB images in 680 and $750 \mathrm{~nm}$ are obtained. The next process is to calculate the image contrast. In this research, there are 24 FFB that are used as training data that consists of 10 ripe and 14 unripe. A total of 77 FFB are used as test data that consists of 38 ripe and 39 unripe. Support Vector Machine (SVM) is used in this research to classify the maturity level of FFB. The accuracy of the training dataset is $66.67 \%$. Meanwhile, the accuracy of the test data is $57.14 \%$. Future works will focus on enhancing accuracy of the system through increasing the number of training and testing data using machine learning.
\end{abstract}

Keywords: $680 \mathrm{~nm}$ image, $750 \mathrm{~nm}$ image, FFB maturity estimation, spectroscopy

\section{PENDAHULUAN}

Berdasarkan data dari Food and Agriculture Organization of the United State (FAO), pada tahun
2010 - 2014, Indonesia merupakan negara yang memiliki luas perkebunan kelapa sawit terbesar dan sebagai penghasil Crude Palm Oil (CPO) terbesar di 
dunia dengan kontribusi produksi mencapai 48,44\%, dan disusul oleh Malaysia di peringkat kedua dengan produksi sebesar 35,60\% (Pertanian 2016). Volume ekspor CPO Indonesia mencapai 22,22 juta ton dengan nilai total mencapai USD 17,14 milyar pada tahun 2013, dan mengalami peningkatan menjadi 29,07 juta ton dengan nilai mencapai USD 20,72 milyar pada tahun 2017 (Statistik, 2018).

\begin{tabular}{ccc}
\multicolumn{2}{c}{ Tabel 1. Standar Kematangan TBS Kelapa Sawit di Indonesia } \\
\hline Fraksi & Kematangan & Jumlah Brondolan \\
\hline 00 & Sangat mentah & 0 \\
0 & Mentah & $1-12,5 \%$ buah luar \\
1 & Kurang matang & $12,5-25 \%$ buah luar \\
2 & Matang I & $25-50 \%$ buah luar \\
3 & Matang II & $50-75 \%$ buah luar \\
4 & Lewat matang I & $75-100 \%$ buah luar \\
5 & Lewat matang II & Buah dalam membrondol \\
- & Tandan kosong & Semua buah membrondol \\
\hline
\end{tabular}

Meskipun merupakan negara penghasil CPO terbesar, tingkat produktivitas tandan buah segar (TBS) kelapa sawit hanya 16,99 ton/ha, menempati posisi ke ketujuh dan masih jauh tertinggal dari Guatemala di peringkat pertama (21,17 ton/ha), Malaysia (21,06 ton/ha), Nikaragua (20,68 ton/ha), Kolombia $(19,89$ ton/ha), Kamerun $(19,14)$, dan Thailand (18,37 ton/ha) di posisi keenam (Outlook Kelapa Sawit 2016, 2017). Produktivitas ini dipengaruhi beberapa faktor, yang pertama adalah di sisi perkebunan kelapa sawit (lingkungan, genetik, teknik budidaya tanaman). Faktor yang kedua adalah pada saat penerimaan TBS kelapa sawit dan pengolahan menjadi CPO di pabrik kelapa sawit. Pada makalah ini, fokus utama penelitian yang dilakukan adalah membantu peningkatan produktivitas di pabrik pengolahan kelapa sawit.

Salah satu masalah utama yang terjadi di pabrik pengolahan kelapa sawit adalah pemilahan TBS kelapa sawit yang terbagi menjadi tiga kelas, yaitu mentah, matang, dan busuk. Pada saat ini, pemilahan atau sortasi TBS ini dilakukan secara manual oleh tenaga manusia (grader). Pemilahan TBS ini bersifat subyektif, karena penilaian tingkat kematangan TBS kelapa sawit dilakukan berdasarkan jumlah brondolan. Secara umum, standar kematangan TBS kelapa sawit yang berlaku di Indonesia dapat dilihat pada Tabel 1.

Terdapat beberapa metode yang telah dikembangkan untuk menentukan tingkat kematangan TBS kelapa sawit secara obyektif. Salah satu metode yang paling banyak diusulkan adalah dengan menggunakan kamera (Kassim, 2014), (Cherie, 2015), (SUTAN, 2016). Dengan menggunakan metode ini, tingkat kematangan buah dapat dideteksi melalui warna TBS kelapa sawit, karena terdapat perbedaan warna antara TBS mentah, matang, dan busuk yang terjadi sebagai akibat dari proses kimia yang terjadi di dalam buah kelapa sawit. Metode lain yang diusulkan adalah dengan menggunakan kamera hiperspektrum (Junkwon, 2009), (Bensaeed, 2014).
Beberapa penelitian estimasi tingkat kematangan TBS kelapa sawit yang memanfaatkan metode spektroskopi menunjukkan bahwa terdapat beberapa daerah panjang gelombang cahaya yang dapat digunakan, yaitu pada daerah cahaya tampak $630-688 \mathrm{~nm}$ (Thoriq, 2016) dan di sekitar $750 \mathrm{~nm}$ (Junkwon, 2009). Selain itu, juga terdapat peluang menggunakan beberapa daerah panjang gelombang di daerah Near-Infrared (NIR), yaitu $1190-1219$ nm, 1408 - $1470 \mathrm{~nm}, 1886$ - $1960 \mathrm{~nm}$, dan 2380 - 2500 $\mathrm{nm}$; meskipun masih memerlukan penelitian lebih lanjut (Iqbal, 2018). Pada umumunya, terdapat dua jenis sumber cahaya pada gelombang tertentu yang dapat digunakan untuk menilai kematangan TBS kelapa sawit, yaitu light-emitting diode (LED) dan laser dioda (Shiddiq, 2017).

Salah satu parameter penting dalam klasifikasi tingkat kematangan TBS kelapa sawit adalah akurasi. Metode klasifikasi yang dapat digunakan untuk mencapai tingkat akurasi yang lebih tinggi adalah Artificial Neural Networks; $k$-Nearest Neighbor; dan Support Vector Machine (Alfatni, 2018).

Tujuan penelitian ini adalah mengembangkan sistem penilaian tingkat kematangan TBS kelapa sawit berbasis citra digital dengan menggunakan sumber cahaya pada panjang gelombang tertentu. Pada penelitian ini digunakan dua LED dengan panjang gelombang tertentu, yaitu $680 \mathrm{~nm}$ dan 750 nm. Proses klasifikasi dilakukan dengan menggunakan aplikasi Classification Learner yang terdapat di program Matlab. Batasan masalah pada penelitian adalah sistem yang dikembangkan hanya mampu membedakan TBS kelapa sawit mentah dengan matang, sedangkan kategori busuk dapat dimasukkan ke dalam kriteria sistem karena keterbatasan data buah TBS kelapa sawit busuk.

\section{METODE}

Sistem penilaian kematangan TBS kelapa sawit yang dikembangkan dalam penelitian ini dapat dilihat di Gambar 1. Sistem ini memiliki empat komponen utama, yaitu LED; mikroprosesor, kamera, dan komputer. LED yang digunakan dalam penelitian ini memiliki dua panjang gelombang yang berbeda, yaitu $680 \mathrm{~nm}$ dan $750 \mathrm{~nm}$, yang berada di daerah cahaya tampak dan NIR. Berdasarkan beberapa hasil penelitian sebelumnya, kedua panjang gelombang ini dapat digunakan untuk melakukan prediksi tingkat kematangan TBS kelapa sawit. Pada panjang gelombang $670-680 \mathrm{~nm}$, terdapat hubungan antara tingkat kematangan TBS kelapa sawit dengan jumlah kandungan klorofil di dalam TBS (Thoriq, 2016), (Bensaeed, 2014), (Utom, 2018). Pada penelitian lain, parameter yang diamati adalah rasio klorofil dengan beta karoten menggunakan panjang gelombang 750 nm (Junkwon, 2009). TBS kelapa sawit matang memiliki kandungan beta karoten yang lebih tinggi dibandingkan TBS kelapa sawit mentah (Basyuni, 2017). Kandungan beta karoten yang lebih tinggi ini membuat warna TBS kelapa sawit matang lebih 
terlihat kuning / merah / oranye cerah apabila dibandingkan dengan yang mentah.
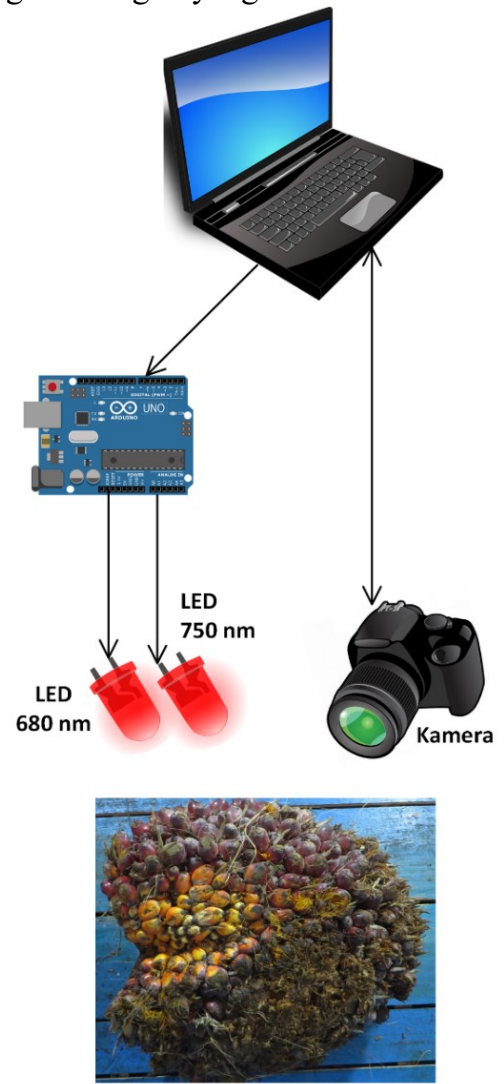

Tanda Buah Segar Kelapa Sawit

Gambar 1. Sistem penilaian kematangan TBS kelapa sawit yang dikembangkan

Salah satu pertimbangan penggunaan LED pada panjang gelombang 680 dan $750 \mathrm{~nm}$ adalah dari sisi harga. (Alfatni, 2018) mengusulkan penggunaan daerah panjang gelombang $1190-1219 \mathrm{~nm}$ dan 1408 - $1470 \mathrm{~nm}$, dimana LED pada rentang ini lebih mahal dibandingkan dengan LED cahaya tampak dan NIR $750 \mathrm{~nm}$. Sedangkan LED pada rentang 1886 - 1960 $\mathrm{nm}$ dan $2380-2500 \mathrm{~nm}$ memiliki harga yang relatif jauh lebih mahal.

Pada penelitian ini, Arduino Uno digunakan sebagai mikrokontroler yang berfungsi untuk mengendalikan LED. Salah satu alasan pemilihannya adalah mikrokontroler ini adalah umum digunakan dengan harga yang relatif murah. Disamping itu, mikrokontroler ini memiliki lebih banyak port, baik digital maupun analog, sehingga akan mempermudah pengembangan sistem. Karena tidak menutup kemungkinan akan dilakukan penambahan jumlah jenis atau panjang gelombang LED yang digunakan.

Komponen utama selanjutnya adalah kamera bertipe digital single-lens reflex camera (DSLR) yang sudah dilengkapi dengan driver software. Hal ini akan memudahkan proses instalasi dan komunikasi kamera dengan komputer. Komponen terakhir adalah komputer yang berfungsi sebagai pusat kendali mikroprosesor dan kamera.
Pengambilan citra TBS kelapa sawit dilakukan dengan menggunakan sumber cahaya LED $680 \mathrm{~nm}$ dan LED $750 \mathrm{~nm}$ secara bergantian. Sehingga diperoleh citra TBS pada panjang gelombang $650 \mathrm{~nm}$ dan citra TBS pada panjang gelombang $750 \mathrm{~nm}$. Citra TBS ini diakuisisi di dalam ruangan tertutup dan gelap, hal ini untuk meminimalkan gangguan dari cahaya luar (sinar matahari dan lampu penerangan). Latar belakang warna biru digunakan dalam akuisisi data citra ini, hal ini karena sangat sedikit sekali warna di alam yang berwarna biru. Tujuan skema akuisisi citra ini adalah untuk mempermudah dalam pengolahan citra, yaitu penghilangan latar belakang lebih mudah dan tidak adanya proses penghilangan derau akibat cahaya luar yang tidak diinginkan.

Citra hasil akuisisi dapat dilihat pada Gambar 2. (a) dan (b) merupakan citra warna RGB dan abu dari TBS kategori mentah yang diberikan sinar cahaya $680 \mathrm{~nm}$, (c) dan (d) merupakan citra warna RGB dan abu dari TBS kategori mentah yang diberikan sinar cahaya $750 \mathrm{~nm}$, (e) dan (f) merupakan citra warna RGB dan abu dari TBS kategori matang yang diberikan sinar cahaya $680 \mathrm{~nm}$, sedangkan (g) dan (h) merupakan citra warna RGB dan abu dari TBS kategori matang yang diberikan sinar cahaya $750 \mathrm{~nm}$.

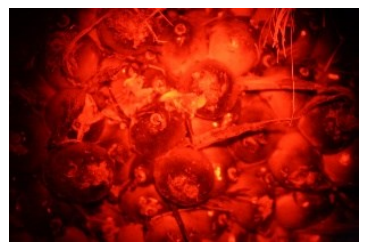

(a)

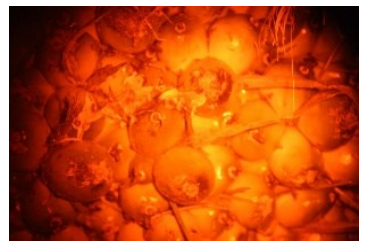

(c)

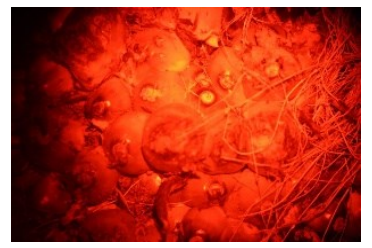

(e)

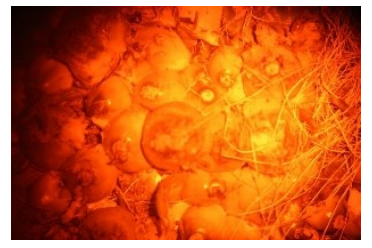

(g)

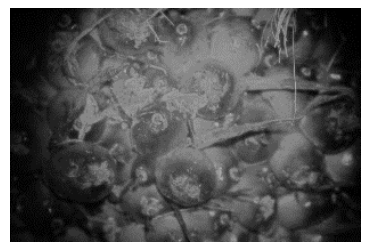

(b)

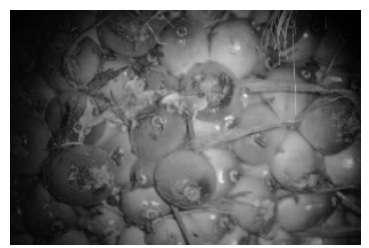

(d)

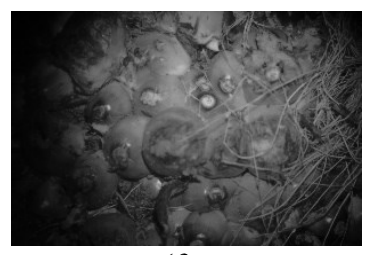

(f)

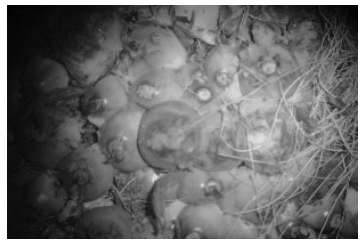

(h)
Gambar 2. Citra (a) warna dan (b) abu TBS mentah 680 nm, (c) warna dan (d) abu TBS mentah $750 \mathrm{~nm}$, (e) warna dan (f) abu TBS matang $680 \mathrm{~nm},(\mathrm{~g})$ warna dan $(\mathrm{h})$ abu TBS matang $750 \mathrm{~nm}$ 
Sistem penilaian tingkat kematangan TBS kelapa sawit yang dikembangkan ini sangat bergantung kepada jarak pengukuran antara TBS dengan kamera sebagai sensor yang akan menangkap cahaya pantulan dari TBS. Pada penelitian ini, asumsi yang digunakan adalah ukuran tinggi TBS sama dan jarak antara TBS dengan kamera dibuat tetap sebesar $30 \mathrm{~cm}$. Penetapan jarak ini diambil berdasarkan hasil percobaan secara empiris, dimana pada jarak ini citra tidak mengalami saturasi dan masih cukup terang untuk dianalisis lebih lanjut.

Pada penelitian ini digunakan pengolah citra berbasis perangkat lunak sumber terbuka yang menggunakan bahasa Java, ImageJ, digunakan pada penelitian ini. Disamping sumber terbuka, salah satu keuntungan menggunakan ImageJ adalah telah tersedia beberapa modul yang dapat digunakan untuk prapengolahan maupun pada saat pengolahan citra. Modul yang akan digunakan dalam penelitian ini adalah nilai kontras citra. Hipotesis dalam penelitian ini adalah terdapat perbedaan nilai kontras citra antara TBS kelapa sawit mentah dan matang. Hal ini berkaitan dengan sifat reflektivitas/pantulan dan absorbasi cahaya pada panjang gelombang tertentu dengan kandungan kimia suatu zat.

Pada ImageJ sudah terdapat modul analisis tekstur berbasis gray-level co-occurrence matrix (GLCM). Karena GLCM beroperasi hanya pada satu kanal citra, maka citra warna RGB (24 bit) perlu diubah menjadi citra abu ( 8 bit) dengan menggunakan modul rgb-to-gray di ImageJ. Berikut ini merupakan persamaan kontras yang digunakan dalam penelitian ini:

$$
\text { Contrast }=\sum_{i, j=0}^{N-1} P_{i j}(i-j)^{2}
$$

Pada persamaan (1), $N$ adalah ukuran GLCM, sedangkan $P_{i j}$ merupakan nilai probabilitas dalam GLCM.

\section{HASIL DAN ANALISIS}

Perubahan tingkat kematangan TBS kelapa sawit dapat dilihat dari perubahan warna buah dengan menggunakan metode spektroskopi. Pada penelitian ini, parameter yang akan dianalisis adalah nilai pantulan cahaya dari TBS kelapa sawit pada panjang gelombang $680 \mathrm{~nm}$ dan $750 \mathrm{~nm}$. Nilai pantulan ini akan diukur dengan menggunakan nilai kontras citra TBS kelapa sawit.

Terdapat dua cara penilaian kematangan TBS kelapa sawit. Cara yang paling umum digunakan adalah dengan penilaian secara visual, meskipun bersifat subyektif, pada saat ini penilaian visual merupakan cara yang disepakati oleh semua pihak (petani, pabrik kelapa sawit, dan pemerintah) dan cara tercepat. Sedangkan cara kedua adalah dengan melakukan ekstraksi kandungan minyak yang terdapat di TBS kelapa sawit yang dapat dikategorikan sebagai pengukuran secara obyektif.
Meskipun demikian, cara ini memerlukan waktu yang lama, sekitar 16 jam. Sehingga tidak memungkinkan diterapkan pada semua TBS kelapa sawit yang masuk ke pabrik kelapa sawit.

Pada penelitian ini, terdapat dua pendekatan yang dilakukan, yaitu data latih yang digunakan diperoleh dari hasil ekstraksi kandungan minyak sawit dalam satu TBS kelapa sawit yang dilakukan di laboratorium. Pendekatan yang kedua adalah data uji yang digunakan diperoleh dari hasil pemilahan yang dilakukan oleh dua orang grader berpengalaman. Idealnya, pembagian kategori ini dilakukan berdasarkan standar kematangan TBS pada Tabel 1 . Pada penelitian yang lain, telah dilakukan pengelompokan menjadi tiga kelas, yaitu mentah, matang, dan busuk. Total data yang digunakan dalam penelitian ini berjumlah 101 TBS kelapa sawit yang dibagi menjadi dua kategori, yaitu matang dan mentah, dengan pertimbangan utama yaitu pada saat pengambilan data di lapangan hanya diperoleh satu TBS kelapa sawit dengan kategori busuk. Sehingga buah ini dimasukkan ke dalam kategori mentah, dengan asumsi bahwa kandungan minyak sawit pada TBS busuk sama dengan mentah.

\subsection{Data Latih}

Data latih yang digunakan pada penelitian ini berjumlah 24 TBS kelapa sawit yang terdiri dari 14 mentah dan 10 matang. Jumlah ini tergolong sedikit, hal ini disebabkan karena penentuan kematangan TBS kelapa sawit yang digunakan sebagai data latih diukur kandungan minyaknya dengan metode ekstraksi. Lama waktu ekstraksi kandungan minyak ini mencapai 16 jam. Oleh karena itu, jumlah data latih yang digunakan dalam penelitian ini hanya 24 TBS kelapa sawit.

Scatter plot nilai kontras dari citra $680 \mathrm{~nm}$ dan $750 \mathrm{~nm}$ yang digunakan sebagai data latih dapat dilihat pada Gambar 3. TBS kelapa sawit kategori mentah ditunjukkan dengan titik warna merah, sedangkan biru adalah TBS kelapa sawit dengan kategori matang.

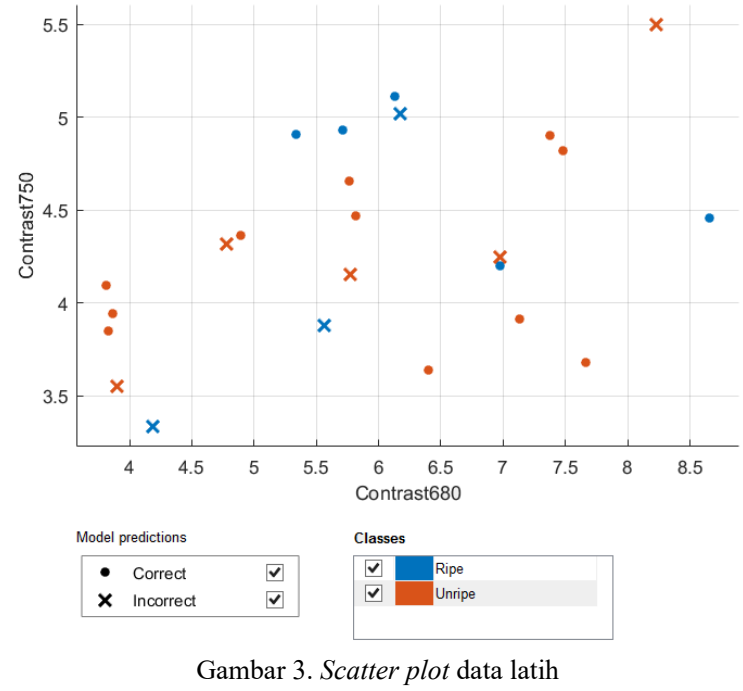


Tabel 1. Confusion Matrix Data Latih

\begin{tabular}{cccc}
\hline & & \multicolumn{2}{c}{ Prediksi } \\
\cline { 3 - 4 } & & Matang & Mentah \\
\hline Ekstraksi & Matang & 7 & 3 \\
kadar minyak & Mentah & 5 & 9 \\
\hline
\end{tabular}

Hasil dari klasifikasi data latih menggunakan SVM ditampilkan dalam confussion matrix di Tabel 1. Akurasi yang diperoleh adalah $66.67 \%$ dengan rincian matang berdasarkan ekstraksi seharusnya berjumlah 10 TBS tetapi terdeteksi oleh sistem hanya 7 TBS yang matang. Untuk kategori mentah, sistem mendeteksi terdapat 9 TBS dengan kategori ini, padahal seharusnya terdapat 14 TBS mentah.

\subsection{Data Uji}

Pada penelitian ini, data uji yang digunakan berjumlah 77 TBS kelapa sawit, dengan komposisi 38 matang dan 39 mentah. Berbeda dengan penilaian tingkat kematangan TBS data latih, tingkat kematangan TBS data uji ini dilakukan oleh dua grader berpengalaman. Hal ini dilakukan karena keterbatasan waktu dan sarana/prasarana untuk melakukan penilaian ke-77 TBS dengan menggunakan metode ekstraksi kandungan minyak.

Gambar 4 memperlihatkan scatter plot nilai kontras dari citra $680 \mathrm{~nm}$ dan $750 \mathrm{~nm}$ yang digunakan sebagai data uji. TBS kelapa sawit dengan kategori mentah ditunjukkan dengan titik warna merah, sedangkan biru adalah TBS kelapa sawit dengan kategori matang. Terlihat bahwa TBS kelapa sawit berkategori mentah cenderung memiliki nilai kontras yang lebih rendah, sedangkan TBS kelapa sawit matang cenderung memiliki nilai kontras yang lebih besar.

Hasil klasifikasi data uji menggunakan SVM dalam bentuk confussion matrix ditampilkan dalam Tabel 2. Terlihat bahwa hasil prediksi oleh sistem terdapat 31 TBS matang dan 14 mentah. Padahal, menurut grader berpengalaman, terdapat 38 TBS matang dan 39 mentah. Sehingga akurasi sistem data uji yang dikembangkan dalam penelitian ini adalah $57,14 \%$.

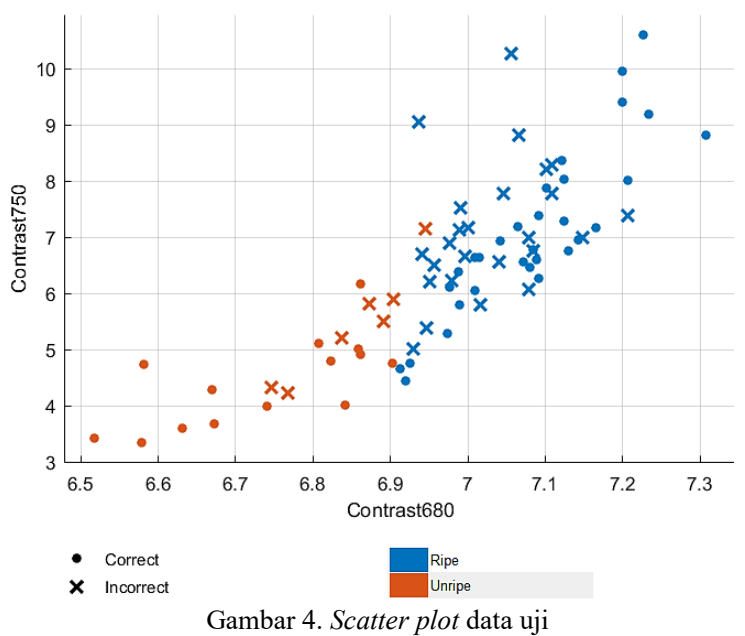

Gambar 4. Scatter plot data uji

\begin{tabular}{cccc}
\multicolumn{2}{c}{ Tabel 2. Confusion Matrix Data Uji } \\
\hline \multirow{2}{*}{ Grader } & \multicolumn{3}{c}{ Prediksi } \\
\cline { 3 - 4 } & Matang & 31 & Mentah \\
\cline { 2 - 3 } & Mentah & 25 & 7 \\
\hline
\end{tabular}

Nilai kontras TBS mentah pada panjang gelombang $680 \mathrm{~nm}$ maupun $750 \mathrm{~nm}$ cenderung lebih rendah dibandingkan dengan TBS matang. Hasil yang diperoleh ini berkaitan dengan perbedaan nilai reflektansi relatif antara TBS mentah dan matang. Nilai absorbsi klorofil yang berada di sekitar panjang gelombang $680 \mathrm{~nm}$, TBS mentah memiliki jumlah klorofil yang lebih banyak. Sehingga, pada panjang gelombang $680 \mathrm{~nm}$, TBS mentah akan lebih banyak menyerap cahaya daripada memantulkannya. Oleh karena itu, nilai kontras citra TBS mentah pada panjang gelombang $680 \mathrm{~nm}$ lebih kecil. Jumlah kandungan klorofil di dalam TBS perlahan akan menghilang seiring dengan kematangan TBS. Oleh karena itu, pada TBS matang, nilai kontras citra TBS matang pada panjang gelombang $680 \mathrm{~nm}$ lebih besar, karena lebih banyak cahaya yang dipantulkan daripada diserap TBS. Sedangkan pada panjang gelombang $750 \mathrm{~nm}$, parameter yang akan diamati adalah rasio antara kandungan klorofil dengan beta karoten. Nilai kontras citra TBS kelapa sawit matang pada panjang gelombang $750 \mathrm{~nm}$ cenderung lebih tinggi dibandingkan dengan yang mentah. Hasil yang diperoleh ini berbeda dengan hasil penelitian lain (Junkwon, 2009) yang menyatakan bahwa nilai reflektansi TBS kelapa sawit mentah pada panjang gelombang $750 \mathrm{~nm}$ lebih tinggi daripada yang matang. Perbedaan hasil ini berkaitan dengan varietas kelapa sawit yang digunakan dalam penelitian.

Meskipun varietas kelapa sawit yang digunakan dalam penelitian ini dan (Junkwon, 2009) sama, yaitu nigrescens, akan tetapi pada kenyataan di pabrik kelapa sawit, terdapat beberapa jenis, misalnya TBS kelapa sawit berwarna merah kehitam-hitaman dan hitam kemerah-merahan. Dengan menggunakan sistem penilaian kemantangan TBS kelapa sawit yang diusulkan, jenis-jenis TBS kelapa sawit ini akan mempengaruhi hasil deteksi. Oleh karena itu, akurasi sistem yang diperoleh pada penelitian masih mencapai 57,14\%. Hasil ini relatif lebih kecil apabila dibandingkan dengan penelitian sebelumnya (Bensaeed, 2014) sebesar 94,54\%. Disamping jenis TBS, faktor lain yang berpengaruh terhadap hasil penelitian ini, jumlah data yang digunakan. Pada penelitian ini, total TBS yang digunakan berjumlah 101 (24 sebagai data latih dan 77 data uji), sedangkan jumlah data yang digunakan pada penelitian (Bensaeed, 2014) hanya 46 TBS dengan varietas nigrescens.

\section{KESIMPULAN}

Pada penelitian awal ini telah dikembangkan sistem penilaian tingkat kematangan TBS kelapa sawit untuk membedakan antara TBS mentah dan matang yang obyektif. Nilai akurasi yang diperoleh 
dari sistem yang dikembangkan ini relatif lebih rendah dibandingkan dengan penelitian yang lain, akurasi data latih baru mencapai $66,67 \%$ dan $57,14 \%$ untuk data uji. Terdapat beberapa faktor yang memengaruhi hasil ini, yaitu terdapat setidaknya dua jenis TBS kelapa sawit nigrescens yang belum dapat terakomodasi ke dalam sistem yang diusulkan. Selain itu, pada data uji di penelitian ini penentuan nilai kematangan TBS kelapa sawit yang dibandingkan adalah grader (subyektif) dengan sistem yang diusulkan (obyektif). Idealnya, penilaian hasil sistem yang dikembangkan ini dibandingkan dengan penilaian kematangan TBS menggunakan ekstraksi kimia yang sama-sama obyektif, seperti pada data latih.

Hasil awal yang diperoleh pada penelitian ini masih dapat diperbaiki untuk meningkatkan nilai akurasi. Beberapa pengembangan yang dapat dan akan dilakukan dalam penelitian lanjutan adalah dengan meningkatkan kualitas dan kuantitas data TBS kelapa sawit yang digunakan sebagai data latih dan uji. Disamping itu, dari sisi teknis, terdapat dua hal utama yang dapat dilakukan untuk meningkatkan akurasi sistem, yang pertama adalah melakukan penelitian dengan menggunakan variasi panjang gelombang yang lebih banyak, terutama di daerah ultraviolet dan NIR, hal ini tentu saja memerlukan pendanaan yang lebih besar karena terkait dengan harga LED yang lebih mahal. Kedua, apabila kualitas dan kuantitas data yang dapat digunakan lebih banyak, maka dapat digunakan metode deep learning (Convolutional Neural Networks / CNN).

\section{DAFTAR PUSTAKA}

ALFATNI, M.S.M., SHARIFF, A.R.M., BEJO, S.K., SAAED, O.M.B., dan MUSTAPHA, A., 2018. Real-time oil palm FFB ripeness grading system based on ANN, KNN and SVM classifiers. IOP Conference Series: Earth and Environmental Science, 169(1), p. 012067.

BASYUNI, M., AMRI, N., PUTRI, L.A.P., SYAHPUTRA, I., dan ARIFIYANTO, D., 2017. Characteristics of fresh fruit bunch yield and the physicochemical qualities of palm oil during storage in North Sumatra, Indonesia. Indonesian Journal of Chemistry, 17(2), pp. 182-190.

BENSAEED, O. M., SHARIFF, A. M., MAHMUD, A. B., SHAFRI, H., dan ALFATNI, M., 2014. Oil palm fruit grading using a hyperspectral device and machine learning algorithm. IOP conference series: Earth and environmental science, 20(1), p. 012017.

CHERIE, D., HERODIAN, S., MANDANG, T., dan AHMAD, U., 2015. Camera-vision based oil content prediction for oil palm (Elaeis Guineensis Jacq) fresh fruits bunch at various recording distances. International
Journal on Advanced Science, Engineering and Information Technology, 5(4), pp. 314322.

IQBAL, Z., HERODIAN, S., dan WIDODO, S., 2018. Evaluasi Non-Destruktif Kandungan Asam Lemak Bebas (ALB) Tanda Buah Segar (TBS) Kelapa Sawit dengan Metode NIR Spektroskopi. Jurnal Teknik Pertanian Lampung, 7(2), pp. 80-87.

JUNKWON, P., TAKIGAWA, T., OKAMOTO, H., HASEGAWA, H., KOIKE, M., SAKAI, K., SIRUNTAWINETI, J., CHAEYCHOMSRI, W., VANAVICHIT, A., ITTINUCHANON, P., and BAHALAYODHIN, B., 2009. Hyperspectral imaging for nondestructive determination of internal qualities for oil palm (Elaeis guineensis Jacq. var. tenera). Agricultural Information Research, 18(3), pp. 130-141.

KASSIM, M.S.M., ISMAIL, W.I.W., RAMLI, A.R., dan Bejo, S.K., 2014. Image clustering technique in oil palm fresh fruit bunch (FFB) growth modeling. Agriculture and Agricultural Science Procedia, 2, pp. 337344.

PERTANIAN, P.D.S.I., 2016. Outlook Kelapa Sawit. Jakarta: Sekretariat Jenderal - Kementerian Pertanian.

SHIDDIQ, M. dan FITRIANI, R., 2017. Membandingkan Kinerja Laser dan LED dalam Pencitraan Fluoresensi Buah Berondolan Kelapa Sawit. Jurnal Penelitian Sains, 19(2).

STATISTIK, B.P., 2017. Statistik Kelapa Sawit Indonesia 2017. Jakarta: BPS.

SUTAN, S.M., ARIFIN, A.D., dan HENDRAWAN, Y., 2016. Identifikasi non-destructive kandungan total pada buah kelapa sawit (Elaeis Guineensis Jacq) berbasis analisis citra. Jurnal Teknologi Pertanian Andalas, 20(1), pp. 50-58.

THORIQ, A., HERODIAN, S., dan SUTEJO, A., 2016. Kajian Karakteristik Spektrum Tandan Buah Segar (TBS) Kelapa Sawit Berdasarkan Tingkat Kematangan Menggunakan Spektrofotometer UV-Vis. Teknotan: Jurnal Industri Teknologi Pertanian, 10(1).

UTOM, S.L., MOHAMAD, E.J., RAHIM, R.A., YEOP, N., AMERAN, H.L.M., KADIR, H.A., MUJ, S.Z.M., dan PUSPPANATHAN, J., 2018. NonDestructive Oil Palm Fresh Fruit Bunch (FFB) Grading Technique Using Optical Sensor. International Journal of Integrated Engineering, 10(1), pp. 35-39. 